\title{
Quantifying predation pressure and the protective role of sheltered basking sites for small snakes in South Africa
}

\author{
Gareth Coombs \\ Grahamstown, Eastern Cape (EC), South Africa. E-mail: coombsgareth@gmail.com.
}

\begin{abstract}
Quantifying predation pressure and the protective role of sheltered basking sites for small snakes in South Africa. Small snakes are frequent prey of predatory birds, reptiles, and mammals. The resulting mortality rate is difficult to quantify given the low likelihood of observing such predation events. However, studies using plasticine snake models have shown that small snakes may experience relatively high rates of predation. Model snakes constructed from slow-drying clay (as a substitute to plasticine) were used to assess the predation rate on small snakes in the Eastern Cape of South Africa. The model snakes were used to test whether snakes basking in semi-shaded positions, with at least half of the body covered by overhanging vegetation are detected by bird and mammal predators. There were relatively high rates of predation, with half of the unconcealed snake models experiencing attacks. The predation rate on partially concealed models is lower than on unconcealed models, but the difference is not statistically significant. Thus, basking in sheltered areas may offer snakes protection against predators; however, predation attempts on concealed models suggests that predators actively seek out areas where prey might hide. This is the first quantification of predation on small snakes in South Africa, and the results generate numerous questions relating to the behavioral ecology of the diverse snake fauna found in this country.
\end{abstract}

Keywords: clay snake models, snake attack risk, snake mortality, snake predation.

\section{Resumo}

Quantificação da pressão de predação e papel dos locais abrigados de aquecimento ao sol em serpentes de pequeno porte na África do Sul. Serpentes de pequeno porte são frequentemente predadas por aves, répteis e mamíferos. A quantificação da taxa de mortalidade devido à predação é dificultada pela baixa probabilidade de se observar eventos de predação. Estudos utilizando modelos de plasticina têm mostrado que serpentes de pequeno porte podem experimentar taxas de predação 
relativamente altas. Avaliei a taxa de predação sobre serpentes de pequeno porte na região do Cabo Oriental da África do Sul usando modelos de serpentes construídos com argila de secagem lenta (como um substituto da plasticina) e testei se serpentes aquecendo-se em posições semi-escondidas, com pelo menos metade do corpo coberta pela vegetação, obtêm proteção contra a detecção por aves e mamíferos predadores potenciais. Meus resultados indicaram taxas de predação relativamente altas, com metade de todos os modelos de serpentes não escondidos tendo experimentado ataques. A taxa de predação sobre os modelos colocados em ambientes parcialmente escondidos foi menor que a taxa registrada para os modelos posicionados em ambientes abertos, mas essa diferença mostrou-se estatisticamente pouco significativa. Os resultados sugerem que aquecer-se em áreas abrigadas pode oferecer proteção contra predadores. As tentativas de predação de modelos escondidos sugerem que os predadores vasculham ativamente áreas em que as presas poderiam se abrigar. Meus resultados representam a primeira quantificação da predação de pequenas serpentes na África do Sul e levantam várias questões relacionadas à ecologia comportamental da diversificada ofidiofauna encontrada nesse país.

Palavras-chave: modelos de argila, mortalidade, risco de ataque, serpentes.

\section{Introduction}

Juvenile snakes and species of small snakes (hereafter referred to as small snakes) frequently are preyed on by a diversity of avian, mammalian, and reptilian predators. Snakes employ several methods to avoid predation, including physical concealment, aposematic coloration (Madsen 1987, Greene and McDiarmid 1981, Brodie III 1992, Brodie III and Janzen 1995, Brodie III and Moore 1995), crypsis, threat displays, body inflation, feigning death (Gehlbach 1970, Burghardt and Greene 1988, Gregory et al. 2007, Muscat et al. 2016), rapid movement, defecation, concealment, and temporal avoidance by being active at times when predators are not. There are a number of records and observations of small snakes forming part of the diet of generalist predators in South Africa (Branch 1998, Skinner and Chimimba 2005), and snakes usually are taken opportunistically. Small snakes of both venomous and non-venomous species are vulnerable to predation (Madsen 1987, Webb and Whiting 2005), but no studies have examined the degree of predation pressure on small snakes in South Africa. Predation of smaller snakes has however been recorded by Underhill et al. (2009).
South Africa is rich in terrestrial snake species with diverse life histories (Branch 1998, Shine et al. 2006), yet little is known about the key life history aspects and ecology of these reptiles. Predation risk is central to shaping the evolution of behavioral ecology in many snake species (Greene 1997, Sparkman et al. 2013). Nearly all species display some behavior or coloration patterns consistent with predation avoidance. These include highly disruptive and naturally colored markings that camouflage the snake, noxious excretion in response to capture (Gerald 2008), rapid predator escape movement, hissing and body inflation, false striking and biting. Natural history observations document that many species of snakes spend a large percentage of time sheltering beneath rocks or in disused termite nests (Lynch 1988, Cottone and Bauer 2013). These behaviours suggest that there is an inherent risk of predation on these snakes in open environments.

To draw conclusions about species-specific adaptive predator-avoidance strategies, we require data on the predation rate on small snakes (Webb and Whiting 2005, Webb et al. 2009). This can be estimated by placing model snakes constructed of a soft, malleable material (e.g., plasticine) in environments where snakes are 
likely to be exposed to predation (Madsen 1987, Webb and Whiting 2005). The body profile of snakes is sufficiently distinctive that it can be recognized visually by predators and attacked without the model moving. Models have been used by many researchers to study various predatory interactions between snakes and predators (Madsen 1987, Brodie III 1992, Hinman et al. 1997, Wüster et al. 2004, Niskanen and Mappes 2005, Webb and Whiting 2006, Valkonen et al. 2011). Snake predators, particularly birds, readily attack these models as if they were attacking live snakes, leaving distinct beak-shaped markings on the mouldable material (Madsen 1987, Webb and Whiting 2005).

Given the vulnerability of small snakes to predation, I aimed to quantify the predation pressure on them through the use of snake models made from non-toxic brown putty. Although many species of snakes in South African are small $(<60 \mathrm{~cm})$ - some as adults and others as neonates of larger species-nothing is known about the relative risks to predation of snakes in this size class. Furthermore, although a host of snake predators have been recorded, the relative importance of these different predators to small snakes in South Africa is unknown.

\section{Materials and Methods}

\section{Study Sites}

The study site is located on a small cattle grazing farm $14 \mathrm{~km}$ south of Grahamstown in the Eastern Cape, South Africa $\left(33^{\circ} 25^{\prime} 7.46^{\prime \prime} \mathrm{S}\right.$, $\left.26^{\circ} 28^{\prime} 41.22^{\prime \prime} \mathrm{E}\right)$. The vegetation of the area is classified as Bhisho Thornveld (Rutherford et al. 2006) and consists of a mixture of open, transformed grassland interspersed with short thorn trees (Acacia natalitia). There are areas of vegetation that consist of denser thorny shrubs that form bushclumps separated by short grass undercover in the study area. I have observed numerous potential snake predators on the farm, including avian predators such as large shrikes [Grey Headed Bush Shrike (Malaconotus blanchoti), Bokmakierie (Telophorus zeylonus), Common Fiscal (Lanius collaris), Southern Boubou (Laniarius ferrugineus), Crowned Hornbills (Tockus alboterminatus), Cape Crow (Corvus capensis)]; raptors [Secretarybird (Sagittarius serpentarius)]; small mammalian predators [African wild Cat (Felis sylvestris lybica), South African Large Spotted Genet (Genetta tigrina), Large Grey Mongoose (Herpestes ichneumon), Yellow Mongoose (Cynictis penicillata), Small Grey Mongoose (Galerella pulverulenta)]; and larger mammalian predators such as Black Backed Jackal (Canis mesomelas) and Chacma Baboons (Papio hamadryas).

\section{Determining the Efficacy of the Model}

Following the technique of Webb and Whiting (2005), I constructed small model snakes about $300 \mathrm{~mm}$ in length from non-toxic putty. The putty consists of finely ground clay mixed with linseed and vegetable oil, which is malleable and easily shaped. Because putty requires more than 10 days to harden, the models constructed from it can be left in the field for several days. Model snakes were shaped and rolled on a flat wooden surface into a long cylindrical shape. I shaped a small head on one side and a sharp tapering tail on the other to mimic the natural body outline of snakes. To test whether predators were deceived into attacking these models, I initially placed a sample of 16 snake models in relatively undisturbed veldt from 19-26 June 2016. Models were placed in open areas on structures or substrates that snakes naturally use as basking sites, which in this study area, consisted mainly of bare soil patches and hard surfaces such as rocks and termitaria. All snake models had an S-shaped posture (e.g., Niskanen and Mappes 2005).

\section{Sheltered Versus Exposed Attack Risk}

In a second experiment August 2015, predation pressure was compared in snakes in open/ 
exposed basking positions (i.e., completely exposed substrates) versus partly concealed basking positions (i.e., sheltered areas). The latter were located in the fringes of shrubs and in partially shaded areas. A typical sheltered basking position would be on the ground 15-30 $\mathrm{cm}$ inside the perimeter of a small shrub. At each site, two snakes were positioned-one on an open exposed basking surface and the other in partial shade provided by overhanging branches of large shrubs or low trees. The pairs of snakes were 1-3 $\mathrm{m}$ apart. Model snakes were left in the field for seven days (11 pairs between 1-6 August and 8 pairs between 6-12 August) and checked for any signs of attack by predators. I noted any obvious patterns in the bite marks on each model and used these data to calculate the total number of models that experienced attacks during each sampling period. I also compared the number of attacks on concealed versus exposed snake models to determine whether concealment reduces encounters with predators. I used a Z-test to test for differences in the proportion of predation attempts on exposed models versus sheltered models.

\section{Main Predators Attacking Model Snakes}

The identity of snake predators was determined by the bite marks present on the models. Tooth marks were identified by multicusp indentations or peg-like tooth marks that are typical of small mammalian carnivores. Bird bites had deep, V-shaped marks flanking both sides of the bite area.

\section{Results}

\section{Determining the Efficacy of the Model}

Of the 16 model snakes first placed on exposed basking areas, 3 (18.8\%) were attacked by predators. Two models had clear tooth indentations of canines, carnassials, or front incisors consistent with attacks by mammals (Figure 1A). The third had distinctive V-shaped markings on either side of the bite indicating that it was attacked by a bird (Figure 1B). One of the model snakes attacked by a mammal (most likely a yellow mongoose) was broken into several pieces (Figure 1A). Honeybees (Apis mellifera) frequently consumed clay from some of the models, but these bite marks were distinctive and were not scored as predation attempts.

Data for the total number of predation attacks (sheltered and exposed combined) varied substantially between the two experimental periods (Table 1). One pair of snakes was excluded from the analysis because one of the pair (1-6 August, $N=20$ ) could not be found. If the first estimate of the number of predation attacks (data used to determine the efficacy of the model) is included, the attack rates seemed to increase in August relative to those in June. In June, only 3 of 16 model snakes had signs of predation attempts $(18.75 \%$, whereas the predation rates between 1-6 August and between 6-12 August are 28.6\% $(N=20)$ and $57.1 \%(N$ $=16$ ), respectively.

\section{Sheltered Versus Exposed Attack Risk}

Both exposed and partially concealed snake models were attacked by birds and small mammals (Table 1), but sheltered models were attacked less frequently than exposed models; the difference is not statistically significant. Two sheltered snake models were attacked between 1 and 6 August, whereas four exposed models were attacked. The same pattern occurred between 6-12 August, with three concealed snake models being attacked and five exposed models attacked (Table 1). Because the sample sizes for the two experimental periods are low $(1-6$ August $=11$ pairs; $6-12$ August $=8$ pairs $)$, I pooled the data to test whether there was a significant difference between predation rates on models in exposed versus sheltered basking sites; the difference was not statistically significant (Proportion exposed models attacked $=0.50$, Proportion sheltered model attacked $=$ $0.277 ; \mathrm{Z}=-1.00, p=0.31$ ). 


\section{Main Predators Attacking Model Snakes}

A total of 17 snake models were attacked. Birds were the primary predators on snake models; they were responsible for 10 attacks (58.8\%), and mammals for the remaining seven $(41.6 \%)$. The patterns of bird attacks ranged from single, small bites to numerous bite marks along the body of the model snake. Birds varied in their technique of attack. Four model snakes had numerous bite marks ( $>20)$, indicating that attacks were sustained and repeated. Most bite marks were distributed along the anterior third of the body, the head, and along the tail. Attack marks by birds on the head suggest that birds recognize the snake head and may endeavour to attack it in an attempt to kill the animal more effectively. In contrast mammal attacks often resulted in the entire body being broken into several pieces.

\section{Discussion}

This study is the first to quantify predation pressure on snakes in South Africa. The clay models effectively elicit predatory behavior in both birds and mammals; thus both taxa seem regularly to attempt to prey on small snakes. Small snakes select basking sites based on thermal suitability (Webb and Whiting 2005); these results suggest that predation may be higher for individuals that bask on exposed sites versus those that bask in more concealed sites. High rates of predation attempts on snake replicas were also documented by Niskanen and Mappes (2005), who found an average of 39\% of model snakes were attacked by predators. My results showed that the total percentage of model snakes that were attacked in exposed basking positions could be as high as 50\%, and the number of models that experienced predator attacks in concealed basking positions was $26.3 \%$. Results by Webb and Whiting (2005) also showed high rates of predation on Hoplocephalus bungaroides, with $13.3 \%$ of snakes on exposed basking position experiencing attacks.
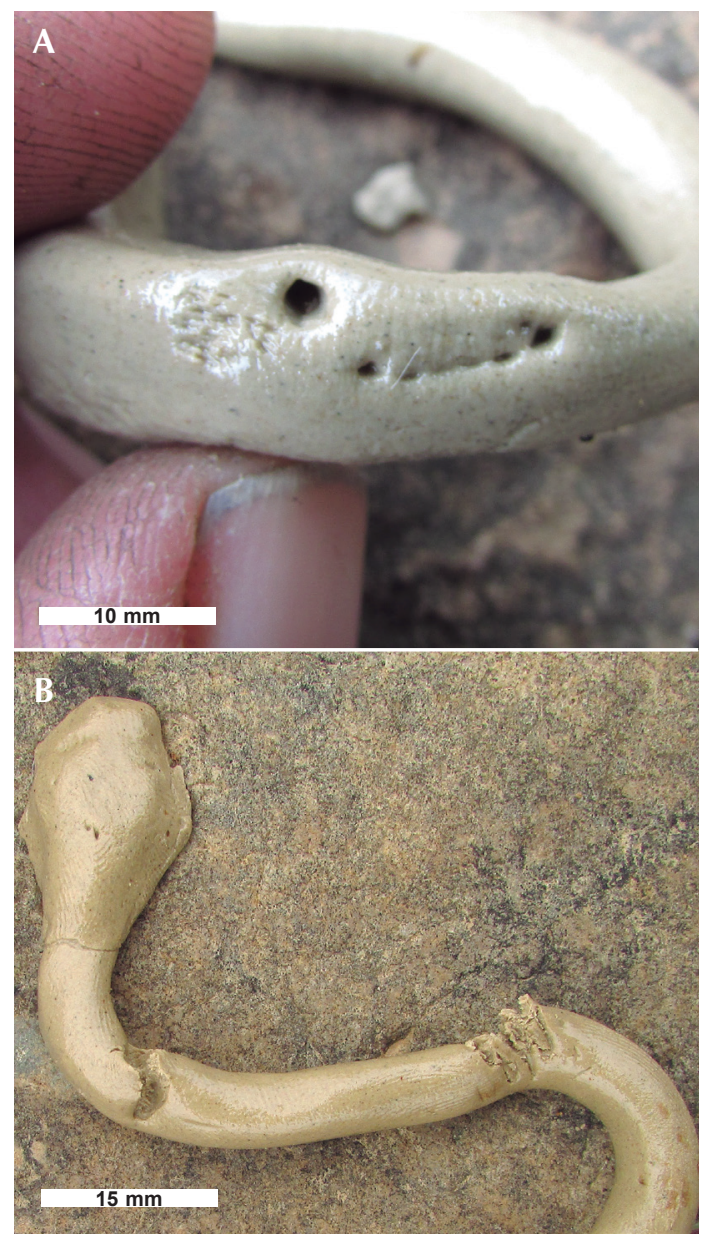

Figure 1. Characteristic bite marks of mammals (A) and birds (B) on model snakes used in this study.

A potential caveat to my findings is the relatively small sample sizes of model snakes used, although sample sizes resemble those of Niskanen and Mappes (2005). Despite the nonsignificant difference between attack rates on sheltered versus non-sheltered models, the higher attack rates on exposed models suggests that larger sample sizes may indicate significant benefits of sheltered basking sites for small snakes. The current study, however, took place on a small farm $(<200$ ha), which limits the 
Table 1. Summary of results testing whether clay model snakes are attacked by predators and whether concealment during basking reduces predation risk in small snakes.

\begin{tabular}{lccccc}
\hline \multicolumn{6}{c}{ Determining the efficacy of model } \\
\hline Date & Sheltered & Exposed & $\begin{array}{c}\text { Total number } \\
\text { Attacked (\%) }\end{array}$ \\
\hline \multicolumn{7}{c}{ Sheltered versus exposed attack risk } \\
\hline Date & - & 16 & $3(18.8)$ & \\
\hline 1-6 August 2016 & 10 & 10 & 6 (30) & $2(18.2)$ & N (40.0) \\
6-12 August 2016 & 8 & 8 & $8(50)$ & $3(37.5)$ & $5(62.5)$ \\
\hline Total & $\mathbf{1 8}$ & $\mathbf{1 8}$ & $\mathbf{1 4}$ & $\mathbf{5 ( 2 7 . 7 )}$ & $\mathbf{9 ( 5 0 . 0 )}$ \\
\hline
\end{tabular}

number of samples that can be placed in the field without risking predators becoming habituated to the presence of an artificial model. Second, despite the small sample sizes, the high number of model snakes that were attacked suggests that small snakes may be subject to a high degree of predation pressure in the study area.

Attacks by avian predators were common, representing nearly $60 \%$ of all attacks. The width of avian bite marks on models was consistently less than $4 \mathrm{~mm}$, which correspondswith the beak width of many of the larger shrike species present in the study area. These include Grey Headed Bush Shrike (Malaconotus blanchoti), Bokmakierie (Telophorus zeylonus), Fiscal Shrike (Lanius collaris), and Southern Boubou (Laniarius ferrugineus). Three of these shrike species (M. blanchoti, $T$. zeylonus and $L$. ferrugineus) hunt inside the canopy of shrubs and trees and also will forage by running on the ground (particularly $T$. zeylonus). This might explain the observation of the large number of attacks that occurred on snakes that were present in concealed positions.

Slightly more than $40 \%$ of attacks were carried out by small mammals, indicating that they are significant predators of small snakes in
South Africa (MacDonald and Nel 1986). The various species of mongoose in South Africa are generalist omnivores that prey opportunistically on snakes (Skinner and Chimimba 2005). Mongoose attack dangerous prey items cautiously (Hinton and Dunn 1967). The exact method by which mongoose kill different snakes is not well documented, but they attack large elapids by immobilizing them with repeated bites on the head and the area immediately behind the head (Hinton and Dunn 1967). This may explain why some of the snake models that were attacked by mammals were brokeninto several pieces. Some species such as suricates or meerkats (Suricatta suricatta) have been documented to attack and consume large venomous elapids such as Naja nivea (Linnaeus, 1758). Two of the mammal attacks on the snake models showed dental patterns consistent with the Chacma Baboon (Papio hamadryas). These animals frequent the study area and occasionally prey on reptiles, although they are cautious of snakes and seldom prey on larger snakes (Hinton and Dunn 1967, Skinner and Chimimba 2005).

This study is the first to estimate predation pressure on small snakes in South Africa with artificial snake models. Given the rich diversity 
of snakes in this country, these kinds of studies can reveal a great deal about the evolutionary pressures that have shaped the behavioral ecology of these reptiles. Future studies based on larger sample sizes and a greater diversity of habitats are needed to quantify predation pressure on small snakes.

\section{Acknowledgments}

The author would like to thank Linda Trueb (Department of Ecology and Evolutionary Biology, Kansas University) for her helpful review and final suggestions on the manuscript.

\section{References}

Branch, W. R. 1998. Field Guide to the Snakes and Other Reptiles of Southern Africa. $3^{\text {rd }}$ edition. Cape Town. Struik Publishers. 399 pp.

Brodie III, E. D. 1992. Correlational selection for color pattern and antipredator behavior in the Garter Snake Thamnophis ordinoides. Evolution 46: 1284-1298.

Brodie III, E. D. and F. J. Janzen.1995. Experimental studies of coral snake mimicry: generalized avoidance of ringed snake patterns by free-ranging avian predators. Functional Ecology 9: 186-190.

Brodie III, E. D. and A. J. Moore. 1995. Experimental studies in coral snake mimicry: do snakes mimic millipedes? Animal Behaviour 49: 534-536.

Burghardt, G. M. and H. W. Greene. 1988. Predator simulation and duration of death feigning in neonate hognose snakes. Animal Behaviour 36: 1842-1844.

Cottone, A. M. and A. M. Bauer. 2013. The vernal spatial ecology and mating behaviors of the Rhombic Skaapsteker, Psammophylax rhombeatus rhombeatus (Serpentes: Psammophiidae), from the Western Cape, South Africa. Copeia 2013: 194-200.

Gehlbach, F. R. 1970. Death-feigning and erratic behavior in leptotyphlopid, colubrid, and elapid snakes. Herpetologica 26: 24-34.

Gerald, G. W. 2008. Feign versus flight: influences of temperature, body size and locomotor abilities on death feigning in neonate snakes. Animal Behaviour 75: 647654.

Greene, H. W. 1997. Snakes: the Evolution of Mystery in Nature. Berkeley. University of California Press. 366 pp.
Greene, H. W. and R. W. McDiarmid.1981. Coral snake mimicry: does it occur? Science 213: 1207-1212.

Gregory, P. T., L. A. Isaac, and R. A. Griffiths. 2007. Death feigning by grass snakes (Natrix natrix) in response to handling by human "predators". Journal of Comparative Psychology 121: 123-129.

Hinman, K. E., H. L. Throop, K. L. Adams, A. J. Dake, K. K. McLauchlan, and M. J. McKone.1997. Predation by free-ranging birds on partial coral snake mimics: the importance of ring width and color. Evolution 51: 10111014.

Hinton, H. E. and A. M. S. Dunn. 1967. Mongooses: Their Natural History and Behaviour. Berkeley. University of California Press. 144 pp.

Lynch, C. D. 1988. Occurrence of Squamata in termitaria in the orange free state, South Africa. Journal of the Herpetological Association of Africa 34: 42-43.

MacDonald, J. T. and J. A. J. Nel. 1986. Comparative diets of sympatric small carnivores. South African Journal of Wildlife Research 16: 115-121.

Madsen, T. 1987. Are juvenile grass snakes, Natrix natrix, aposematically coloured? Oikos 48: 265-267.

Muscat, E., E. L. Rotenberg, and I. F. Machado. 2016. Death-feigning behaviour in an Erythrolamprus miliaris (Linnaeus, 1758) water snake in Ubatuba, São Paulo, southeastern Brazil (Dipsadidae). Herpetology Notes 9: 95-97.

Niskanen, M. and J. Mappes. 2005. Significance of the dorsal zigzag pattern of Vipera latastei gaditana against avian predators. Journal of Animal Ecology 74: 1091-1101.

Rutherford, M. C., L. Mucina, M. C. Lotter, G. J. Bredenkamp, J. H. L. Smit, R. Scott-Shaw, D. B. Hoare, P. S. Goodman, H. Bezuidenhout, L. Scott, F. Ellis, L. W. Powrie, F. Siebert, T. H. Mostert, B. J. Henning, C. E. Venter, K. G. T. Camp, S. J. Siebert, W. S. Matthews, J. E. Burrows, L. Dobson, N. van Rooyen, E. Schmidt, P. J. D. Winter, P. J. du Preez, R. A. Ward, S. Willamson, and P. J. S. Hurter. 2006. Savanna Biome. Pp. 439-539 in L. Mucina and M. C. Rutherford (eds.), The Vegetation of South Africa, Lesotho and Swaziland. Pretoria. South African National Biodiversity Institute.

Shine, R., W. R. Branch, J. K. Webb, P. S. Harlow, T. Shine, and J. S. Keough. 2006. Ecology of cobras from southern Africa. Journal of Zoology 272: 183-193.

Skinner J. D. and C. T. Chimimba. 2005. The Mammals of the Southern African Subregion. $3^{\text {rd }}$ edition. Cape Town. Cambridge University Press. 872 pp. 
Sparkman, A. M., A. M. Bronikowski, J. G. Billings, D. Von Borstel, and S. J. Arnold. 2013. Avian predation and the evolution of life histories in the Garter Snake Thamnophis elegans. American Midland Naturalist 170: 66-85.

Underhill, L. G., R. B. Sherley, B. M. Dyer, and R. J. M. Crawford. 2009. Interactions between snakes and seabirds on Robben, Schaapen and Meeuw Islands, Western Cape province, South Africa. Ostrich 80: 115118.

Valkonen, J., M. Niskanen, M. Björklund, and J. Mappes. 2011. Disruption or aposematism? Significance of dorsal zigzag pattern of European vipers. Evolutionary Ecology 25: $1047-1063$.

Webb, J. K. and M. J. Whiting. 2005. Why don't small snakes bask? Juvenile broad-headed snakes trade thermal benefits for safety. Oikos 110: 515-522.
Webb, J. K. and M. J. Whiting. 2006. Does rock disturbance by superb lyrebirds (Menura novaehollandiae) influence habitat selection by juvenile snakes? Austral Ecology 31: $58-67$.

Webb, J. K., R. M. Pringle, and R. Shine. 2009. Intraguild predation, thermoregulation, and microhabitat selection by snakes. Behavioural Ecology 20: 271-277.

Wüster, W., C. S. E. Allum, I. B. Bjargardóttir, K. L. Bailey, K. J. Dawson, J. Guenioui, J. Lewis, J. McGurk, A. G. Moore, M. Niskanen, and C. P. Pollard. 2004. Do aposematism and Batesian mimicry require bright colours? A test, using European viper markings. Proceedings of the Royal Society of London, Biology Sciences 27: 2495-2499.

Editor: Stephen J. Richards 